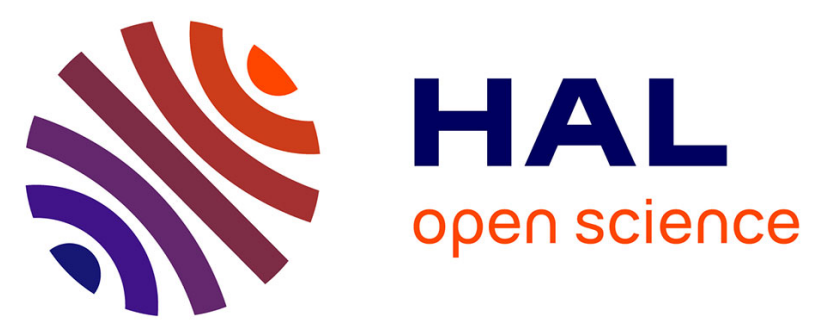

\title{
The ways of the lustre: looking for the Tunisian connection
}

S.Y. Waksman, Claudio Capelli, Trinitat Pradell, Judit Molera

\section{To cite this version:}

S.Y. Waksman, Claudio Capelli, Trinitat Pradell, Judit Molera. The ways of the lustre: looking for the Tunisian connection. Marcos Martinón-Torres (ed.). Craft and science: International perspectives on archaeological ceramics, Bloomsbury Qatar Foundation, pp.109-116, 2014, 10.5339/uclq.2014.cas.ch12 . hal-02010339

\section{HAL Id: hal-02010339 \\ https://hal.univ-lyon2.fr/hal-02010339}

Submitted on 6 Feb 2020

HAL is a multi-disciplinary open access archive for the deposit and dissemination of scientific research documents, whether they are published or not. The documents may come from teaching and research institutions in France or abroad, or from public or private research centers.
L'archive ouverte pluridisciplinaire $\mathbf{H A L}$, est destinée au dépôt et à la diffusion de documents scientifiques de niveau recherche, publiés ou non, émanant des établissements d'enseignement et de recherche français ou étrangers, des laboratoires publics ou privés. 


\title{
The ways of the lustre: Looking for the Tunisian connection
}

\author{
Yona Waksman ${ }^{\mathrm{a}}$, Claudio Capelli ${ }^{\mathrm{b}}$, Trinitat Pradell ${ }^{\mathrm{c}}$ and Judit Molera ${ }^{\mathrm{d}}$

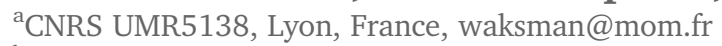 \\ bDIP.TE.RIS, Università degli Studi di Genova, Italy, capelli@dipteris.unige.it \\ ${ }^{c}$ Dpt. FEN. Universitat Politècnica de Catalunya, Barcelona, Spain, Trinitat.Pradell@upc.edu \\ ${ }^{\mathrm{d}}$ GRMAiA, EPS, Universitat de Vic, Spain, Judit.Molera@uvic.cat
}

\begin{abstract}
Recent excavations at the Fatimid and Zirid site of Sabra al-Mansuriya near Kairouan (Tunisia) provide the first evidence of lustreware production in medieval Ifriqiya, in the $10^{\text {th }}-11^{\text {th }}$ centuries $\mathrm{AD}$. As the Fatimid dynasty moved from Ifriqiya to Egypt to establish its capital in Fustat (Cairo), technological connections with the Egyptian lustreware could be expected. Tunisian lustreware may also be the link in the transmission of the technique towards Muslim Spain. It represents a new piece of the puzzle of understanding the diffusion of lustre technology from the East to the West of the Mediterranean. The composition and microstructure of the bodies and glazes, and the micro- and nano-structure of the lustre layer are compared in a preliminary approach to the technological relationships between Tunisian, Egyptian, and Spanish lustrewares.
\end{abstract}

\section{Introduction}

The site of Sabra al-Mansuriya, founded by the Fatimids on the outskirts of Kairouan (Tunisia), was occupied according to written documents from 947/948 to $1057 \mathrm{AD}$. Recent excavations were carried out at the site by a FrenchTunisian team directed by P. Cressier (CNRS UMR 5648, France) and M. Rammah (INP, Tunisia) (Cressier and Rammah 2004; 2006). Of particular interest to us are the remains of an artisanal area with a glass and a pottery kiln (Gragueb and Tréglia 2005; Thiriot forthcoming). Laboratory investigations of ceramics, including wasters, indicated a local manufacture of lustreware in Sabra alMansuriya (Fig. 1; Waksman et al. forthcoming; Capelli et al. 2011). The characterisation of its body and glaze is complemented in the present paper by a preliminary study of the properties of the lustre layer.

Although lustreware tiles dated back as early as the $9^{\text {th }}$ century AD ornate Kairouan's great mosque, they are likely to be imports from Mesopotamia (Bobin et al. 2003), and the excavations at Sabra al-Mansuriya provide the first evidence for lustreware production in medieval Ifriqiya. One may wonder which role it could have played in the transmission of the lustreware technique. As the Fatimid dynasty moved from Ifriqiya to Egypt in 972 to establish its capital in Fustat (Cairo), technological connections with the Egyptian lustreware could be expected. Tunisian lustreware may also be the link in the transmission of the technique towards Muslim Spain. Comparisons of technological characteristics of Tunisian and other lustreware productions (Bobin et al. 2003; 2005; Borgia et al. 2004; Mason 2004; Darque-Ceretti et al. 2005; Pradell et al. 2005; 2007; 2008a; 2008b; 2008c; Chabanne et al. 2006; 2008; Polvorinos del Rio et al. 2006; Smith et al. 2006; Molera et al. 2007; Roqué et al. 2007; Polvorinos del Rio and Castaing 2010), especially Egyptian and Spanish ones, were expected to shed some light on its role in the diffusion of the lustre technology in the Mediterranean regions.

\section{Materials and methods}

Chemical analyses of the bodies were carried out by WDXRF at the Laboratoire de Céramologie (CNRS UMR5138, Lyon, France), allowing the determination of twenty-four elements. Oxygen was added by stoichiometry and the results normalised to $100 \mathrm{wt} \%$; all the major and minor elements were determined (totals before normalisation are typically between 98 and 102\%; see Waksman 2011 for details of the analytical protocol and the calibration procedure). Seventeen elements (major and minor elements $\mathrm{MgO}, \mathrm{Al}_{2} \mathrm{O}_{3}, \mathrm{SiO}_{2}, \mathrm{~K} 2 \mathrm{O}, \mathrm{CaO}, \mathrm{TiO}_{2}, \mathrm{Fe}_{2} \mathrm{O}_{3}$, $\mathrm{MnO}$; trace elements $\mathrm{V}, \mathrm{Cr}, \mathrm{Ni}, \mathrm{Zn}, \mathrm{Rb}, \mathrm{Sr}, \mathrm{Zr}, \mathrm{Ba}, \mathrm{Ce}$ ) are generally used to classify ceramics into groups of similar chemical compositions. The latter may correspond to the production of the same workshop, under certain conditions mainly related to the geological environment (Picon 1993).

Petrographic (thin section) and SEM-EDS analyses of bodies and glazes were performed at the archaeometry laboratory of the DIP.TE.RIS (University of Genoa, Italy). Chemical microanalyses of glazes were carried out on at least 


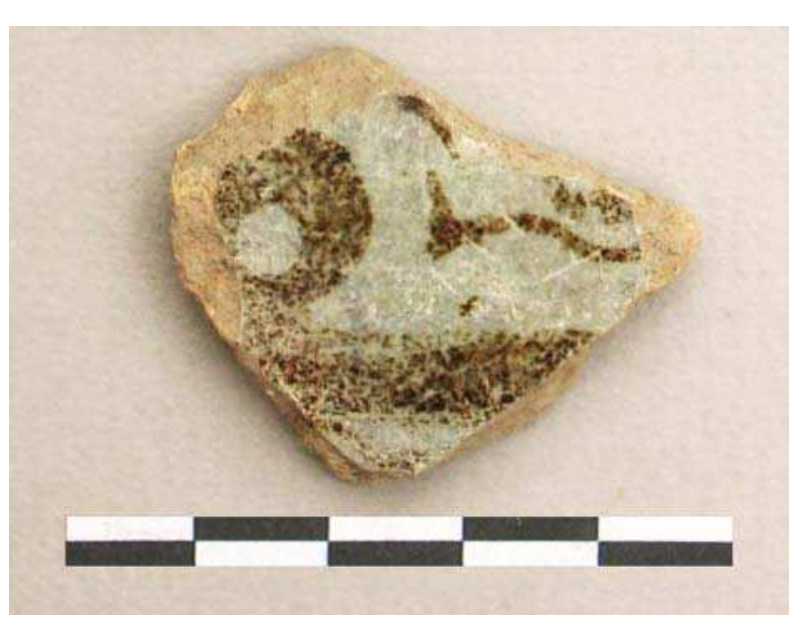

Figure 1. Example of lustreware manufactured at Sabra al-Mansuriya (sample TUN134; scale $5 \mathrm{~cm}$ ).

3 selected points (spot mode) along a cross-section of the glaze from the base to the surface, avoiding alterations, interface, reaction zones, and mineral inclusions. The composition was normalised to $100 \mathrm{wt} \%$ after subtraction of $\mathrm{SnO}_{2}$ values, attributable to the presence of cassiterite (the opacifier, added separately from other glaze ingredients).

Chemical analysis of the lustre layers has been performed by SEM-EDS at SCT-UB (University of Barcelona, Spain). Chemical analyses were carried out over the surface of the glazes (lustre decorations and plain glaze). The penetration depth of the microprobe is greater (about $2 \mu \mathrm{m}$ ) than the lustre layer thickness (probably between 0.1 and $1 \mu \mathrm{m}$ ), so that the analyses provide information on the overall composition. Oxygen was added by stoichiometry and the results normalised to $100 \mathrm{wt} \%$, with all the major and minor elements being determined (in all cases, the totals before normalisation were between 94.2 and $99 \%$, which is reasonable considering that we were working directly on the lustre and glaze surfaces). Although the chemical composition of the lustre layer itself was only indirectly assessed, the copper and silver determined correspond only to the lustre layer, and therefore their $\mathrm{Cu} /(\mathrm{Cu}+\mathrm{Ag})$ ratio corresponds to their ratio in the lustre layer itself.

UV-Vis diffuse reflectance (DR) was measured directly from the surface of the lustre layers. A small circular spot of $5 \mathrm{~mm}$ diameter was used to collect the data. The data are presented as $\log (1 / \mathrm{DR})$, which is equivalent to absorption for highly absorbing materials. The characteristic Surface Plasmon Resonance (SPR) absorption peaks associated with the metal nanoparticles appear in the UV-Vis spectra providing information concerning the type and size of the nanoparticles (Kreibig and Vollmer 1995).

\section{Characterisation of Tunisian lustreware}

As part of a larger assemblage from Sabra al-Mansuriya, eight samples of Tunisian lustreware were analysed by WDXRF to determine the composition of the body. Two of them were further characterised by petrography and SEM-EDS analysis of the glazes (TUN3 and TUN8). Two others were investigated for the properties of their lustre layer (TUN134 and TUN118). The latter sample, a waster of lustreware, was not considered representative of the finished product and was thus not included here.

\section{Bodies}

In terms of chemical composition, Tunisian lustreware produced in Sabra al-Mansuriya have calcareous clay bodies, containing high percentages of silica due to abundant quartz inclusions (see petrographic features infra, and Table 1). Other elements possibly related to the sand fraction, such as zirconium, titanium, chromium, and nickel, are only present in small quantities. The clay proportion is low, as can be seen from the low aluminium concentrations. The iron, potassium, and rubidium concentrations are low as well, the latter falling under detection limits. Occasional high contents of sodium, strontium, and manganese are likely to derive from secondary phases developed during burial (Walter and Besnus 1989; Picon 1991).

Under the polarising microscope, the bodies show a carbonate-rich clay matrix and abundant inclusions mainly composed of quartz grains. Most of them are small $(<0.3$ $\mathrm{mm}$ across) and angular in shape, but the greater ones $(<0.8 \mathrm{~mm}$ across $)$ are rounded and characterised by abraded surfaces, well visible under the stereomicroscope or the SEM, which suggests an aeolian origin. Limestone fragments and relics of calcareous microfossils (foraminifera) are present in accessory amounts.

The origin of the raw materials can be related to calcareous marine sediments, whereas the dominant presence of (aeolian) quartz is a typical feature of most of the Tunisian ceramic productions of all ages and sediments (Capelli and Bonifay 2007).

Table 1. Chemical analysis by WD-XRF of bodies of lustrewares found in Sabra al-Mansuriya (Tunisia): local production and Egyptian imports. Major and minor elements in oxides wt $\%$, trace elements in ppm; n: number of samples.

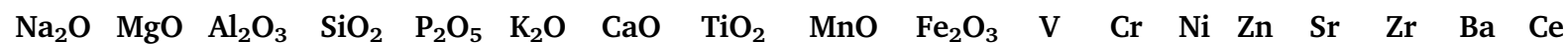

Tunisian lustreware $(\mathrm{n}=9)$

\begin{tabular}{|c|c|c|c|c|c|c|c|c|c|c|c|c|c|c|c|c|c|c|}
\hline $\mathrm{m}$ & 2.42 & 2.08 & 9.19 & 64.57 & 0.23 & 1.08 & 15.28 & 0.466 & 0.2964 & 3.76 & 82 & 69 & 26 & 78 & 606 & 134 & 210 & 65 \\
\hline$\sigma$ & 0.40 & 0.21 & 1.40 & 4.33 & 0.05 & 0.22 & 2.84 & 0.071 & 0.0549 & 0.51 & 9 & 10 & 2 & 10 & 148 & 11 & 29 & 9 \\
\hline \multicolumn{19}{|c|}{ Egyptian lustreware $(n=22)$} \\
\hline & 1.27 & 3.51 & 12.82 & 54.02 & 0.37 & 1.28 & 17.95 & 1.060 & 0.0887 & 7.12 & 134 & 114 & 43 & 92 & 905 & 291 & 335 & 97 \\
\hline & 0.28 & 0.30 & 1.10 & 1.71 & 0.07 & 0.29 & 1.77 & 0.147 & 0.0104 & 0.83 & 23 & 14 & 7 & 7 & 101 & 19 & 23 & \\
\hline
\end{tabular}




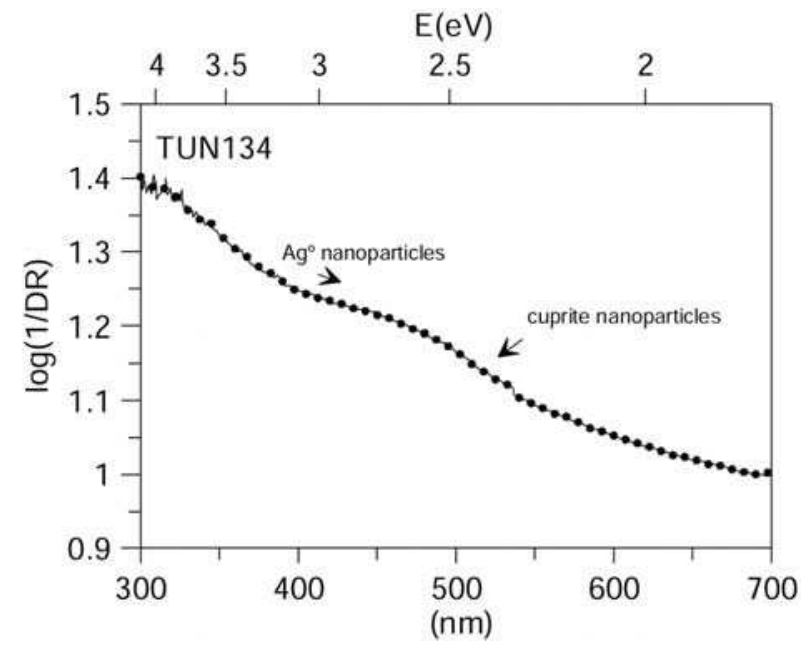

Figure 2. UV-Vis spectrum corresponding to sample TUN134. The presence of metal silver nanoparticles, as well as cuprite nanoparticles, is indicated.

The studied lustreware samples are not very homogeneous in their chemical and petrographic features. They are however well integrated in the range of ceramic products attributed to the region of Kairouan (Waksman et al. forthcoming), a region within which clays are likely to present similar characteristics (Louhichi and Picon 1983; Ben Amara et al. 2005). A more precise attribution of lustrewares to Sabra al-Mansuriya can however be inferred from the glaze analysis (infra) and from the discovery at the site of a lustreware waster (TUN118, supra).

\section{Glazes}

Glazes have homogeneous thicknesses $(0.2-0.3 \mathrm{~mm})$ and include several gas bubbles, while no relic inclusions are present. Cassiterite (the opacifier) forms abundant and relatively large microaggregates. Both glazes are extensively weathered, mainly into Pb-carbonates.

In terms of chemical composition, the lustreware glazes fall in the field of lead-alkali glazes (Tite et al. 1998; $\mathrm{PbO} 23-27 \%, \mathrm{SiO}_{2} 56-57 \%, \mathrm{Na}_{2} \mathrm{O} 7-8 \%, \mathrm{~K}_{2} \mathrm{O} 2-3 \%, \mathrm{CaO}$ $\left.4-5 \%, \mathrm{Al}_{2} \mathrm{O}_{3} 1 \%\right)$. They are very similar in microstructure and chemical compositions to glazed wasters from the pottery workshop (Waksman et al. forthcoming).

\section{Lustre layer}

Lustre is distinguished from other glaze decorations by its characteristic procedure of production. Lustre technology involves firstly the application of the lustre paint (typically containing sulphur and silver and/or copper-based compounds mixed with clay) on the previously glazed ceramic, and then firing it in a combination of oxidisingthen-reducing atmosphere at temperatures between 500 and $600{ }^{\circ} \mathrm{C}$. The temperature is low enough to avoid glaze softening, but high enough to facilitate the ionic diffusion. The formation of molten mixed sulphates in the lustre paint containing silver, copper and alkalis results in the ionic exchange of the $\mathrm{Ag}^{+}$and $\mathrm{Cu}^{+}$ions from the paint by $\mathrm{Na}^{+}$ and/or $\mathrm{K}^{+}$from the glaze (Pradell et al. 2005). Silver and copper are incorporated into the glaze, and, following the introduction of a reducing atmosphere, precipitate forming small metal nanoparticles (from 2 to $50 \mathrm{~nm}$ in size). The nanoparticles appear concentrated in a thin layer (well below 1 micrometre) close to the glaze surface. This nanostructure, that is the nature and size of the nanoparticles and the thickness and concentration of nanoparticles in the layer, is directly responsible for the characteristic colours and metallic shine shown by lustres. In particular, green, yellow, orange, and brown are the colours shown by silver lustres (containing silver metal nanoparticles), while pinkish, ruby red, and crimson are the colours shown by copper lustres (containing copper metal nanoparticles) (Molera et al. 2007). The metallic shine is 'golden' for silver lustres and 'coppery' for copper lustres. The concentration of small metal nanoparticles in a thin layer close to the glaze surface is the chief feature of lustre and is a direct consequence of the lustre production process (Pradell et al. 2007; Gutierrez et al. 2010).

\section{UV-Vis spectroscopy}

For the determination of the presence of metal nanoparticles, one of the most useful techniques is UV-Vis spectroscopy. Measuring the reflectance by means of an Ulbritch Integrating Sphere, it is possible to evaluate the absorption spectrum. The presence of metal nanoparticles in the layers gives a very characteristic profile (Kreibig and Vollmer 1995). Figure 2 shows the UV-Vis absorption spectra corresponding to the lustre sample TUN134. The profile is related to the presence of silver metal nanoparticles (peak at 430-450 ) and cuprite nanoparticles (shoulder at $500 \AA$ ), as indicated in the figure.

\section{Chemical analysis}

The presence of metallic nanoparticles in the glaze is certainly an indication of lustre, but it is not sufficient; for instance, red Chinese glazes contain copper nanoparticles, but they are not lustres (Wood 1999, 167-87). However, the exchange of $\mathrm{Ag}^{+}$and $\mathrm{Cu}^{+}$from the paint by $\mathrm{Na}^{+}$and $\mathrm{K}^{+}$ from the glaze, characteristic of the lustre production process, implies that for each atom of silver/copper present in the lustre one atom of $\mathrm{Na} / \mathrm{K}$ has been removed from the glaze. This inverse unity correlation is seen by plotting the chemical atomic composition of $\mathrm{Ag}$ and $\mathrm{Cu}$ from the lustre

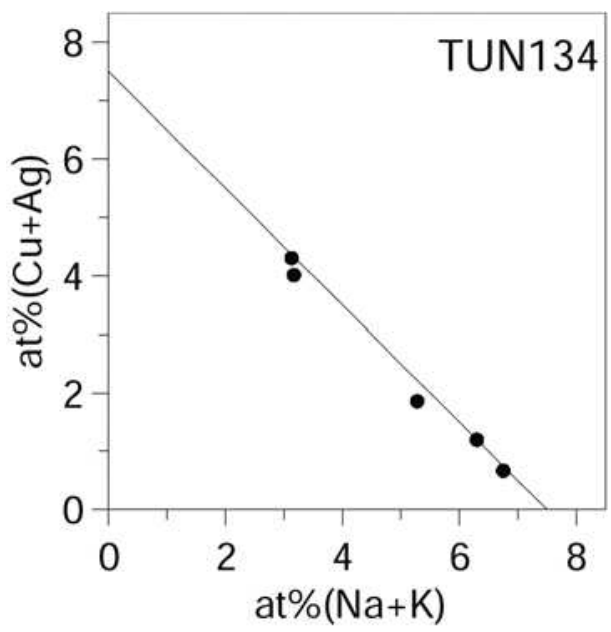

Figure 3. Plot of the atomic concentration of copper and silver versus that of potassium and sodium, showing the characteristic inverse unity correlation found in lustres. 

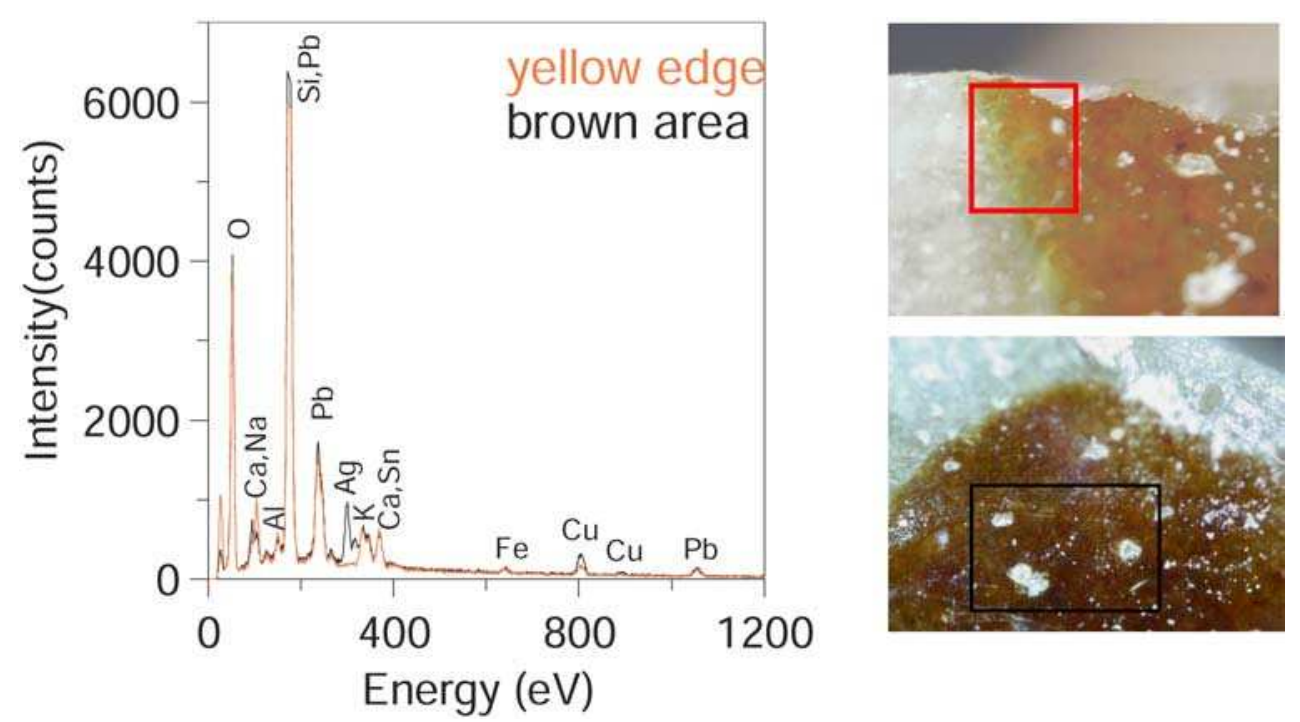

Figure 4. Colour and chemical analysis of the brown and yellow areas in sample TUN134.

surfaces versus the alkali atomic content (Molera et al. 2007). Figure 3 shows the correlation found for the Tunisian lustre and demonstrates that it was produced following the lustre procedure described above.

The studied Tunisian lustre (TUN134) has a characteristic brownish colour typical of silver lustres. They contain silver nanoparticles and also copper as $\mathrm{Cu}^{+}$and/or $\mathrm{Cu}^{2+}$, however without forming metal copper nanoparticles. The lustre also shows a yellow colour at the edges of the lustre decoration, as seen in Figure 4. The edges of lustre decorations often have different colours and chemistry, the most characteristic being red or coppery edges. Red and coppery edges contain a high ratio of $\mathrm{Cu} /(\mathrm{Ag}+\mathrm{Cu})$, and copper forming $\mathrm{Cu}^{\circ}$ and cuprite $\left(\mathrm{Cu}_{2} \mathrm{O}\right)$ nanoparticles. Red and coppery edges are found in some Fatimid (Egypt, $12^{\text {th }}$ century $\left.\mathrm{AD}\right)$, Persian $\left(12^{\text {th }}\right.$ and $13^{\text {th }}$ centuries $\left.\mathrm{AD}\right)$, and Spanish (Paterna, late $13^{\text {th }}-14^{\text {th }}$ century $A D$ ) lustre productions (Molera et al. 2001; Smith et al. 2006; Pradell et al. 2008a). The reason for the formation of red edges was discussed in detail elsewhere (Smith et al. 2006); it is related to the easier access of the furnace atmosphere and heat to the lustre paint/glaze contact area. The initial oxidising conditions facilitate the penetration of copper into the glaze and the further reducing conditions produce the reduction of copper ions into cuprite and metal copper nanoparticles (Molera et al. 2007). Something similar happened for TUN134 - a higher relative concentration of copper is found at these yellow edges as compared to the brown central part of the lustre decoration. The chemical analysis of both the brown and the yellow areas are shown in a comparative plot in Figure 4 and in Table 2. We can see that the yellow area is also richer in copper in relative terms. The colour is yellow because in this case the reduction atmosphere has not been strong enough to produce the precipitation of copper metal nanoparticles, but only small cuprite nanoparticles $(2-30 \mathrm{~nm})$ that show a characteristic deep yellow colour (Molera et al. 2007).

Another feature observed is the reduced amount of lead in some areas of the glaze and lustre surface. This is very typical in samples which have been buried, and may be related to the leakage of lead during burial (the SEM-EDS analysis of the glazes of samples TUN 3 and 8, which are strongly weathered into $\mathrm{Pb}$-carbonates, supports this hypothesis). This has also been found in other Islamic lustres (Pradell et al. 2008a; 2008c, Roqué et al. 2007). Moreover, they also contain quite high amounts of tin, and because of its heterogeneous distribution in the glaze, some of the analyses may indicate particularly large amounts of tin, which are not the average content of tin of the glazes.

Sample TUN134 shows typical copper contents of about $2-5$ $\mathrm{wt} \%$ and a very heterogeneous distribution of silver, varying

Table 2. Chemical analysis by SEM-EDS of the lustre layer in sample TUN134, in wt\%. Comparison between the yellow edges and the brown central part of the lustre decoration. Detection limits are below $0.1 \mathrm{wt} \%$ for both silver and copper.

\begin{tabular}{|c|c|c|c|c|c|c|c|c|c|c|c|c|c|c|}
\hline & wt $\%$ & O & $\mathrm{Na}$ & $\mathrm{Mg}$ & $\mathrm{Al}$ & Si & $\mathbf{K}$ & $\mathrm{Ca}$ & $\mathrm{Fe}$ & $\mathrm{Cu}$ & $\mathrm{Ag}$ & Sn & $\mathrm{Pb}$ & $\mathrm{Cu} /(\mathrm{Cu}+\mathrm{Ag})$ \\
\hline \multirow[t]{5}{*}{ TUN134 } & Brown area & 31.9 & 1.7 & 0.4 & 0.8 & 27.7 & 1.4 & 1.0 & 0.7 & 4.6 & 7.0 & 3.8 & 19.2 & 40.0 \\
\hline & & 37.2 & 4.9 & 0.4 & 0.9 & 30.5 & 2.0 & 1.0 & 0.8 & 1.5 & 0.2 & 4.9 & 15.6 & 40.0 \\
\hline & & 32.4 & 1.7 & 0.4 & 0.9 & 28.1 & 1.4 & 1.1 & 0.6 & 5.3 & 7.3 & 3.5 & 17.4 & 42.0 \\
\hline & Yellow edge & 34.0 & 4.1 & 0.4 & 1.2 & 29.9 & 2.2 & 1.6 & 0.9 & 2.7 & 0.3 & 4.5 & 18.3 & 91.5 \\
\hline & & 24.4 & 2.6 & 0.4 & 1.1 & 35.1 & 2.3 & 1.4 & 1.0 & 3.6 & 0.4 & 5.7 & 22.0 & 89.4 \\
\hline
\end{tabular}


from 0.2 to $7 \mathrm{wt} \%$. This is very typical in Islamic lustres, with copper being more homogeneously distributed over the entire surface, while silver appears more heterogeneously distributed, forming silver-rich areas. For the studied lustre layer (TUN134), the average copper and silver contents of the brown lustre are $7.1 \mathrm{wt} \% \mathrm{Ag}$ and $5.0 \mathrm{wt} \% \mathrm{Cu}$, respectively. The copper to silver ratio (as defined in Molera et al. 2001) is $\mathrm{wt} \% \mathrm{Cu} /(\mathrm{Cu}+\mathrm{Ag})=40 \%$ (Table 2 ).

\section{Comparative data}

Comparative data were available both from lustreware imports to Sabra al-Mansuriya and from previous studies on lustreware. The former only include so far body and glaze analyses, and mostly concern ceramics which are likely to be Egyptian productions from Fustat (Waksman et al. forthcoming; Capelli et al. 2011). The latter involve a larger variety of lustrewares originating from museum collections, whose dating and origin is mainly based on art historical criteria; they are summarised in Table 3 (Borgia et al. 2004; Mason 2004; Darque-Ceretti et al. 2005; Smith et al. 2006; Roqué et al. 2007; Chabanne et al. 2008; Pradell et al. 2008a; 2008b; 2008c; Gutierrez et al. 2010; Polvorinos del Rio and Castaing 2010).

Egyptian lustrewares from Sabra al-Mansuriya are dated according to the period of occupation of the site (mid-10th - mid-11th century AD). From a technological viewpoint, their calcareous clay body belongs to the same category of pastes as the Tunisian ones. The two productions can however easily be differentiated in the framework of provenance studies, on the basis of both elemental (Table 1) and petrographic features of the bodies.

Their glaze features show clear compositional and technological differences (Capelli et al. 2011; Waksman et al. forthcoming). As for the texture, Egyptian glazes are characterised by many gas bubbles and several angular to rounded relic inclusions of quartz, plagioclase, and K-feldspar, which suggest the use of impure alluvial sand. Cassiterite is less abundant than in Tunisian wares.

SEM-EDS analyses of Egyptian imports found at Sabra alMansuriya, including two Egyptian lustrewares, show the presence of homogeneous lead-alkali glazes, but their composition ( $\mathrm{PbO} 40-41 \%, \mathrm{SiO}_{2} 46-48 \%, \mathrm{Na}_{2} \mathrm{O} 4-5 \%$, $\left.\mathrm{K}_{2} \mathrm{O} 2-3 \%, \mathrm{CaO} 1 \%, \mathrm{Al}_{2} \mathrm{O}_{3} 3 \%\right)$ and especially the relative ratios of $\mathrm{PbO} / \mathrm{SiO}_{2}, \mathrm{Na}_{2} \mathrm{O} / \mathrm{K}_{2} \mathrm{O}$, and $\mathrm{CaO} / \mathrm{Al}_{2} \mathrm{O}_{3}$ are very different from the Tunisian lead-alkali production, confirming the use of different recipes.

These imports at Sabra al-Mansuriya are only one of several lustreware productions attributed to Fustat, which differ in terms of technology and chronology (Mason 2004; Chabanne et al. 2006; Pradell et al. 2008a; 2008b). A selection of sherds from the Ashmolean Museum, representing four different groups, had been characterised for their body, glaze, and lustre layer (Table 3). In the Fatimid lustreware from Fustat, both stonepastes and calcareous pastes were used, and within the calcareous pastes we encounter three different types: fine calcareous, coarse calcareous, and very high calcareous. It is not clear if this is related to productions of different quality. The bodies corresponding to the end of the Fatimid production tend to be of the very high calcareous type. Stonepastes continued to be used in Persia (Kashan) and also in Syria (Raqqa) in later productions (late $12^{\text {th }}$ and $13^{\text {th }}$ centuries AD) (Mason 2004; Pradell et al. 2008a, 2008b). In contrast, calcareous ceramic pastes were used in the later Islamic and Hispano Moresque productions from Spain (Paterna, Seville, and Manises; $14^{\text {th }}$ and $15^{\text {th }}$ centuries $\mathrm{AD}$ ) (Polvorinos del Rio and Castaing 2010). Tunisian lustreware also has a calcareous body.

The glazes from the Fustat lustreware are generally speaking lead-rich (about $30-40 \mathrm{wt} \% \mathrm{PbO}$ ), although the later very high calcareous pastes have glazes poorer in lead (about 25 $\mathrm{wt} \% \mathrm{PbO}$ ). The glazes from later Persian lustreware contain about $25 \mathrm{wt} \% \mathrm{PbO}$, while those used in the Syrian lustreware are lead free. In contrast, later Spanish productions have glazes richer in lead (35-45 wt\% $\mathrm{PbO}$ ) and potassium.

Concerning the composition of the lustre layers, the Fatimid lustres from Fustat have a $\mathrm{Cu} /(\mathrm{Cu}+\mathrm{Ag})$ ratio between 10 and 20\%; they are richer in silver than the lustre from Tunisia. This difference may be explained, at least in part, by the use of more oxidising conditions for the Tunisian lustres. However, it may also indicate an intentional decrease in the silver content, either to obtain a cheaper lustreware for the local market, or to modify the colour of the lustre designs. The increase of copper content in the lustre designs is responsible for the change of the colour from green-yellow to orange-brown. The lustreware productions from Persia and Syria $\left(12^{\text {th }}\right.$ and $13^{\text {th }}$ centuries $\mathrm{AD}$ ) are also richer in copper (Pradell et al. 2008b) than the Fatimid lustres from Fustat, and have a characteristic brown colour similar to the Tunisian lustre studied here. In Spain, the lustreware becomes particularly copper-rich in the second half of the $14^{\text {th }}$ century and in the $15^{\text {th }}$ century (Polvorinos del Rio et al. 2006; Smith et al. 2006; Roqué et al. 2007), and in these cases the colour of the lustre designs becomes redder and copper-like.

\section{Concluding remarks}

A preliminary study of Tunisian lustreware manufactured at Sabra al-Mansuriya confirms that it presents the features of lustre, with a mechanism of ionic exchange between the copper and silver atoms of the lustre and the alkalis of the glaze followed by a (partial) reduction to metallic $\mathrm{Cu}$ and $\mathrm{Ag}$. Further analyses on an extended assemblage are planned, to confirm these features and characterise the structure and the thickness of the lustre layer.

Another subject of interest is the possible role of the Tunisian lustreware production in the transmission of this technique in the Mediterranean, especially between Egypt and Spain. It actually presents some global resemblance with examples of Egyptian and Spanish lustreware, when compared to others attributed to Iraq, Persia, and Syria: fine calcareous clay body (as opposed to stonepaste), leadalkali tin-opacified glaze (as opposed to low-lead-alkali or alkali glaze), 'true' lustre with lustre shine. However, they also differ in several respects.

Tunisian and Egyptian lustrewares found at Sabra alMansuriya, in mid- $10^{\text {th }}$ to mid- $11^{\text {th }}$ century $\mathrm{AD}$ contexts, show noticeable differences in the chemical and textural features of the glaze. The characterisation of the lustre layer shows that Egyptian lustrewares from the Ashmolean Museum, dated back to the period between the $10^{\text {th }}$ and the $12^{\text {th }}$ century $\mathrm{AD}$, are richer in silver than the Tunisian sample studied. A direct technological connection between 
Table 3. General characteristics of the Tunisian sample TUN134 and of other Islamic lustreware productions $\left({ }^{1}\right.$ Pradell et al. $2008 \mathrm{c} ;{ }^{2}$ Pradell et al. 2008a; ${ }^{3}$ Smith et al. 2006; Roqué et al. 2007 and Chabanne et al. 2008; ${ }^{4}$ Borgia et al. 2004; ${ }^{5}$ Darque-Ceretti et al. 2005; ${ }^{6}$ Mason 2004; ${ }^{7}$ Gutierrez et al. 2010).

\begin{tabular}{|c|c|c|c|c|c|c|c|c|c|}
\hline & Dating & $\begin{array}{l}\text { Origin or } \\
\text { supposed origin }\end{array}$ & Body & Glaze & Lustre & Lustre colour & Lustre shine & $\begin{array}{c}\% \mathrm{Cu} / \\
(\mathrm{Cu}+\mathrm{Ag})\end{array}$ & $\begin{array}{l}\text { Oxidation } \\
\text { state }\end{array}$ \\
\hline \multirow[t]{2}{*}{$\operatorname{Iraq}^{1,5,6,7}$} & 9th $\mathrm{AD}$ & Basra & $\begin{array}{l}\text { fine } \\
\text { calcareous }\end{array}$ & $\begin{array}{l}\text { low-lead-alkali } \\
\text { (5-10\% PbO), tin }\end{array}$ & polychrome & $\begin{array}{l}\text { brown-green \& } \\
\text { amber }\end{array}$ & $\begin{array}{l}\text { only green } \\
\text { golden }\end{array}$ & $40-90$ & $\mathrm{Cu}^{+}, \mathrm{Cu}^{2+}, \mathrm{Ag}^{\mathrm{O}}$ \\
\hline & 10th $\mathrm{AD}$ & Basra & $\begin{array}{l}\text { fine } \\
\text { calcareous }\end{array}$ & $\begin{array}{l}\text { low-lead alkali } \\
(10-15 \% \text { PbO), tin }\end{array}$ & monochrome & green-yellow & golden & $0-10$ & $\mathrm{Ag}^{0}, \mathrm{Cu}^{+}$ \\
\hline \multirow[t]{3}{*}{ Egypt $^{2,6,7}$} & 10th - 11th $\mathrm{AD}$ & Fustat & $\begin{array}{l}\text { fine } \\
\text { calcareous }\end{array}$ & $\begin{array}{l}\text { lead-alkali } \\
(30-40 \% \mathrm{PbO}) \text {, tin }\end{array}$ & monochrome & $\begin{array}{l}\text { green, yellow, } \\
\text { amber }\end{array}$ & golden & 10 & $\mathrm{Ag}^{0}, \mathrm{Cu}^{+}$ \\
\hline & 12th $\mathrm{AD}$ & Fustat & $\begin{array}{l}\text { highly } \\
\text { calcareous }\end{array}$ & $\begin{array}{l}\text { lead-alkali } \\
(25-40 \% \mathrm{PbO}) \text {, tin }\end{array}$ & monochrome & $\begin{array}{l}\text { yellow, amber, } \\
\text { brown }\end{array}$ & golden & $10-30$ & \\
\hline & 12th $\mathrm{AD}$ & Fustat & stonepaste & $\begin{array}{l}\text { lead-alkali } \\
(25-40 \% \mathrm{PbO}) \text {, tin }\end{array}$ & monochrome & $\begin{array}{l}\text { yellow, amber, } \\
\text { brown }\end{array}$ & golden & 10 & \\
\hline Tunisia & $\begin{array}{l}\text { mid 10th - } \\
\text { mid 11th } \mathrm{AD}\end{array}$ & $\begin{array}{l}\text { Sabra al- } \\
\text { Mansuriya }\end{array}$ & $\begin{array}{l}\text { fine } \\
\text { calcareous }\end{array}$ & $\begin{array}{l}\text { lead-alkali } \\
(20-30 \% \mathrm{PbO}) \text {, tin }\end{array}$ & monochrome & $\begin{array}{l}\text { brown/yellow } \\
\text { edges }\end{array}$ & golden & 40 & $\mathrm{Ag}^{0}, \mathrm{Cu}^{+}$ \\
\hline \multirow[t]{2}{*}{ Spain $^{3,5}$} & $\begin{array}{l}\text { late 13th - } \\
1 \text { st half 14th } \\
\quad \mathrm{AD}\end{array}$ & Paterna & $\begin{array}{l}\text { fine } \\
\text { calcareous }\end{array}$ & $\begin{array}{l}\text { lead-alkali } \\
(40 \% \mathrm{PbO}) \text {, tin }\end{array}$ & monochrome & $\begin{array}{l}\text { brown/red } \\
\text { edges }\end{array}$ & golden & $10-30$ & $\mathrm{Ag}^{0}, \mathrm{Cu}^{0}$ \\
\hline & $\begin{array}{l}\text { 2nd half of } \\
\text { 14th - 15th } \\
\text { AD }\end{array}$ & Paterna & $\begin{array}{l}\text { fine } \\
\text { calcareous }\end{array}$ & $\begin{array}{l}\text { lead-alkali } \\
(30 \% \mathrm{PbO}) \text {, tin }\end{array}$ & monochrome & $\begin{array}{l}\text { brown reddish/ } \\
\text { red edges }\end{array}$ & golden & $40-50$ & $\mathrm{Ag}^{0}, \mathrm{Cu}^{0}$ \\
\hline Persia $^{2,4,6}$ & $\begin{array}{l}\text { late 12th - } \\
\text { 13th } A D\end{array}$ & Kashan & stonepaste & $\begin{array}{l}\text { lead-alkali } \\
(20-25 \% \mathrm{PbO}) \text {, tin }\end{array}$ & monochrome & $\begin{array}{l}\text { brown/red } \\
\text { edges }\end{array}$ & golden & $40-60$ & $\mathrm{Ag}^{0}, \mathrm{Cu}^{0}, \mathrm{Cu}^{+}$ \\
\hline \multirow[t]{2}{*}{ Syria ${ }^{2,6}$} & $\begin{array}{l}\text { late 12th - } \\
\text { 13th } \mathrm{AD}\end{array}$ & $\begin{array}{l}\text { Ma'arrat al } \\
\text { Numan }\end{array}$ & stonepaste & alkali & monochrome & red & no & 100 & $\mathrm{Cu}^{+}, \mathrm{Cu}^{0}$ \\
\hline & 13th $\mathrm{AD}$ & Raqqa & & & monochrome & $\begin{array}{l}\text { brown, } \\
\text { yellow-green }\end{array}$ & no & 70 & $\mathrm{Cu}^{+}, \mathrm{Ag}^{0}$ \\
\hline
\end{tabular}


the two productions is thus not supported by the presently available data. However, the Egyptian production is complex and diversified in its technological features (Mason 2004), and we cannot rule out any connection whatsoever at the present stage of the study. Further research on ceramics of attested provenance and originating from stratified excavations, such as those at Istabl' Antar, Cairo (Gayraud et al. forthcoming), would be particularly helpful.

In addition, the Tunisian lustreware examined in the present study shows more resemblance, in its copper to silver ratio with the later (second half of the $14^{\text {th }}-15^{\text {th }}$ century $\mathrm{AD}$ ) than with the early lustreware production at Paterna (end of the $13^{\text {th }}$ - first half of the $14^{\text {th }}$ century AD). It does not thus appear as its precursor. However, the chronological gap between the Sabra al-Mansuriya and Paterna productions calls for data on the earliest lustrewares manufactured in Spain.

This preliminary study of a Tunisian lustreware production is important as it brings in new data on ceramics which are well-defined archaeologically - a rare feature in the field of lustreware studies. It however opens more questions than it provides answers at the present stage of research, and makes clear how little we still know about the transmission of the lustre technique between the Eastern and the Western parts of the Mediterranean.

\section{References}

Ben Amara A., Schvoerer M., Thierrin-Michael G. and Rammah M., 2005, Distinction de céramiques glaçurées aghlabides ou fatimides ( $\mathrm{IX}^{\mathrm{e}}-\mathrm{XI}^{\mathrm{e}}$ siècles, Ifriqiya) par la mise en évidence de différences de texture au niveau de l'interface glaçure - terre cuite. ArcheoSciences, Revue d'Archéométrie, 29, 35-42.

Bobin O., Schvoerer M., Ney C., Rammah M., Daoulatli A., Pannequin B. and Gayraud R.P., 2003, Where did the lustre tiles of the Sidi Oqba mosque (AD 836-63) in Kairouan come from? Archaeometry, 45, 569-577.

Bobin O., Schvoerer M., Chabanne D., Ney C., Lahaye M., Labrugère C. and Guette A., 2005, Localisation et distribution par spectroscopie Auger des constituants colloïdaux des décors de lustre métallique de céramiques glaçurées. In Décor de lustre métallique et céramique glaçurée, (eds. M. Schvoerer, C. Ney and P. Peduto), 39-45, Scienze e materiali del patrimonio culturale 7, Edipuglia, Bari.

Borgia I., Brunetti B., Giulivi A., Sgamellotti A., Shokouhi F., Oliaiy P., Rahighi J., Lamehi-Rachti M., Mellini M. and Viti C., 2004, Characterisation of decorations on Iranian (10th-13th century) lustreware. Applied Physics A, 79, 257-261.

Capelli C. and Bonifay M., 2007, Archéométrie et archéologie des céramiques africaines: une approche multidisciplinaire. In LRCW2. Late Roman Coarse Wares, Cooking Wares and Amphorae in the Mediterranean: Archaeology and Archaeometry, (eds. M. Bonifay and J.-C. Tréglia), 551-568, British Archaeological Reports International Series 1662 (II), Archaeopress, Oxford.

Capelli C., Waksman Y., Cabella R., Gragueb S. and Tréglia J.-C., 2011, Il contributo delle analisi di laboratorio allo studio delle ceramiche nordafricane: l'esempio di Sabra al-Mansûriya (dati preliminari). In La céramique maghrébine du haut Moyen Âge (VIIIe - Xe siècle). État des recherches, problèmes et perspectives, (eds. P. Cressier and E. Fentress), 221-232, Roma.

Chabanne D., Aucouturier M., Bouquillon A. and Darque-Ceretti E., 2006, Les céramiques à décor de lustre métallique, un traitement de surface nanométrique traditionnel. Connaissance des productions islamiques depuis le IX ${ }^{\text {ème }}$ siècle jusqu'à la Renaissance. International Conference "Matériaux 2006", Dijon novembre 2006, Fédération Française des Matériaux, Dijon.

Chabanne D., Bouquillon A., Aucouturier M., Dectot X. and Padeletti G., 2008, Physico-chemical analyses of Hispano-Moresque lustred ceramic: a precursor for Italian majolica? Applied Physics A, 92, 11-18.

Cressier P. and Rammah M., 2004, Une autre ville califale: Sabra al-Mansuriya. Cuadernos de Madinat al-Zahra, 5, 241-255.

Cressier P. and Rammah M., 2006, Sabra al-Mansuriya: une nouvelle approche archéologique. Comptes rendus des séances de l'Académie des Inscriptions et Belles Lettres, 2006, 113-133.

Darque-Ceretti E., Hélary D., Bouquillon A. and Aucouturier M., 2005, Gold-like lustre: a nanometric surface treatment for the decoration of glazed ceramics in ancient Islam, Moresque Spain, and Renaissance Italy. Surface Engineering, 21, 352-358.

Gayraud R.-P., Vallauri L., with the collaboration of Guionova G., Tréglia J.-C. and the participation of C. Capelli and S.Y. Waksman, forthcoming, Fouilles d'Istabl' Antar (Fustat). Céramiques d'ensembles des IXe et Xe siècles, IFAO, Cairo.

Gragueb S. and Tréglia J.-C., 2005, Observations préliminaires sur la céramique du secteur 6. In Fouilles de Sabra al-Mansuriya. Kairouan, Tunisie. Programme de coopération archéologique franco-tunisienne, campagne 2005, (eds. P. Cressier and M. Rammah), 98-116. Unpublished excavations report.

Gutierrez P.C., Pradell T., Molera J., Smith A.D., ClimentFont A. and Tite M.S., 2010, Color and Golden Shine of Silver Islamic Luster. Journal of the American Ceramic Society, 93, 2320-2328.

Kreibig U. and Vollmer M., 1995, Optical properties of metal clusters, Springer Series in Materials Science 25, Springer, Berlin and New York.

Louhichi A. and Picon M., 1983, Importation de matériel céramique ifriqiyen en Mauritanie. Revue d'Archéométrie, 7, 45-58.

Mason R., 2004, Shine like the sun. Lustre-painted and associated pottery from the medieval Middle East, Mazda Press, Costa Mesa, California and the Royal Ontario Museum, Toronto.

Molera J., Mesquida M., Perez-Arantegui J., Pradell T. and Vendrell M., 2001, Lustre recipes from a medieval workshop in Paterna. Archaeometry, 43, 455-460.

Molera J., Bayés C., Roura P., Crespo D. and Pradell T., 2007, Key parameters in the production of medieval 
lustre colours and shines. Journal of the American Ceramic Society, 90, 2247-2257.

Picon M., 1991, Quelques observations complémentaires sur les altérations de composition des céramiques au cours du temps. Cas de quelques alcalins et alcalinoterreux. Revue d'Archéométrie, 15, 117-122.

Picon M., 1993, L'analyse chimique des céramiques: bilan et perspectives. Archeometria della Ceramica. Problemi di Metodo, Atti $8^{\circ}$ Simposio Internazionale della Ceramica (Rimini 1992), 3-26, Centro Ceramico, Bologna.

Polvorinos del Rio A. and Castaing J., 2010, Lustredecorated ceramics from a $15^{\text {th }}$ to $16^{\text {th }}$ century production in Seville. Archaeometry, 52, 83-98.

Polvorinos del Rio A., Castaing J. and Aucouturier M., 2006, Metallic nano-particles in lustre glazed ceramics from the $15^{\text {th }}$ century in Seville studied by PIXE and RBS. Nuclear Instruments and Methods B, 249, 596-600.

Pradell T., Molera J., Roqué J., Smith A.D., Crespo D., Pantos E. and Vendrell M., 2005, Ionic-exchange mechanism in the formation of medieval lustre decorations. Journal of the American Ceramic Society, 88, 1281-1289.

Pradell T., Climent-Font A., Molera J., Zucchiatti A., Ynsa M.D., Roura P. and Crespo D., 2007, Metallic and non-metallic shine in luster: an elastic ion backscattering study. Journal of Applied Physics, 101, 1-8.

Pradell T., Molera J., Smith A.D. and Tite M.S., 2008a, Early Islamic lustre from Egypt, Syria and Iran (10th to 13th century AD). Journal of Archaeological Science, 35, 2649-2662.

Pradell T., Molera J., Smith A.D., Climent Font A. and Tite M.S., 2008b, Technology of Islamic lustre. Journal of Cultural Heritage, 9, e123-e128.

Pradell T., Molera J., Smith A.D. and Tite M.S., 2008c, The invention of lustre: Iraq 9th and 10th centuries AD. Journal of Archaeological Science, 35, 1205-1215.
Roqué J., Molera J., Pérez-Arantegui J., Calabuig C., Portillo J. and Vendrell-Saz M., 2007, Lustre colour and shine from the Olleries Xiques workshop in Paterna (Spain), 13th century AD: nanostructure, chemical composition and annealing conditions. Archaeometry, 49, 511-528.

Smith A.D., Pradell T., Roqué J., Molera J., Vendrell-Saz M., Dent A.J. and Pantos E., 2006, Colour variations in 13th century Hispanic Lustre - an EXAFS study. Journal of Non-Crystalline Solids, 352, 5353-5361.

Thiriot J., forthcoming, L'atelier de potiers du "palais sud-est" de Sabra al-Mansuriya. In Sabra al-Mansûriya. Capitale fatimide, (eds. P. Cressier and M. Rammah).

Tite M.S., Freestone I., Mason R., Molera J., Vendrell-Saz M. and Wood N., 1998, Lead glazes in antiquity - Methods of production and reasons for use. Archaeometry, 40, 241-260.

Waksman S.Y., 2011, Ceramics of the 'Serçe Limani type' and Fatimid pottery production in Beirut. Levant, 43, 201-212.

Waksman S.Y., Capelli C. and Cabella R., forthcoming, Etudes en laboratoire des céramiques de Sabra al-Mansuriya et de la région de Kairouan. In Sabra al-Mansûriya. Capitale fatimide, (eds. P. Cressier and M. Rammah).

Walter V. and Besnus Y., 1989, Un exemple de pollution en phosphore et en manganèse de céramiques anciennes. Revue d'Archéométrie, 13, 55-64.

Wood N., 1999, Chinese glazes, Black Publishers, London.

\section{ACKNOWLEDGEMENTS}

We would like to thank the French-Tunisian mission at Sabra al-Mansuriya, and especially P. Cressier and J.-C. Tréglia, and M. Delavenne for improving Fig.1. 